Open Access

\title{
Implications of corporate governance on financial performance: an analytical review of governance and social reporting reforms in India
}

\author{
Puneeta Goel@
}

\section{Correspondence:} puneetagoel@gmail.com

Amity College of Commerce and Finance, J-1 Block, II Floor, Amity University, Sector 125, Noida 201313, India

\begin{abstract}
Currently the corporate governance reforms in India are at cross roads where though the intention behind the reforms is good yet there is a need to look for a complete solution addressing country specific challenges in Indian context. Keeping pace with developments at international level, India also introduced reforms for improving corporate, social and environment disclosures. This paper explores the effectiveness of these corporate governance reforms by analyzing the corporate governance practices followed by Indian companies in two reform periods (FY 2012-13 as Period 1) and (FY 2015-16 as Period 2). Considering mandatory regulations as per clause 49 of Listing agreement with Securities exchange board of India and the governance norms in the new Company Act, 2013, a corporate governance performance (CGP) index is developed to measure corporate governance score of Indian companies. Though there is a significant improvement in corporate governance structures implied by Indian companies but the number of independent directors inducted in the board decreases after the reforms in period 2. All the sectors under study show a significant improvement in following corporate governance practices after the reforms. The study reported a significant relationship between integrated framework of total corporate social performance and financial performance only in period 1. Corporate governance reforms do not impact financial linkages in Indian market in period 2.
\end{abstract}

Keywords: Corporate governance, Corporate governance and social responsibility reforms, Financial performance

\section{Introduction}

The economic success of an organization is not only dependent on efficiency, innovation and quality management but also on compliance of corporate governance principles. Implementation of corporate governance standards improves financial performance of the company as well as positively impacts internal efficiency of the firms (Tadesse, 2004) in developed economies. However, lack of transparency and poor disclosure practices reduce effectiveness of corporate governance mechanism. Though, global financial crisis and major corporate scandals have reinforced the merit of good

(c) The Author(s). 2018 Open Access This article is distributed under the terms of the Creative Commons Attribution 4.0 International License (http://creativecommons.org/licenses/by/4.0/), which permits unrestricted use, distribution, and reproduction in any medium, provided you give appropriate credit to the original author(s) and the source, provide a link to the Creative Commons license, and indicate if changes were made. 
corporate governance structures in enhancing firms' performance and sustainability in the long run (Ehikioya, 2009).

Corporate governance aims at facilitating effective monitoring and efficient control of business. Its essence lies in fairness and transparency in operations and enhanced disclosures for protecting interest of different stakeholders (Arora and Bodhanwala, 2018). Corporate governance structures are expected to help the firm perform better through quality decision making (Shivani et al. 2017). A wider definition given by Maier (2005) states that "Corporate governance defines a set of relationships between a company's management, its board, its shareholders and its stakeholders." Good corporate governance "ensures that corporations take into account the interests of a wide range of constituencies, as well as of the communities within which they operate, and that their boards are accountable to the company and the shareholders" (Organization for Economic Cooperation and Developement, 1999). Corporate governance was originally developed to protect shareholder's interest but gradually it has gained importance for other stakeholders and society (Jizi, Salama, Dixon, Startling, 2014).

Corporate governance identifies the role of directors and auditors towards shareholders and other stakeholders. Corporate governance is significant for shareholders as it increases confidence in the company for better return on investment. For other stakeholders like employees, customers, suppliers, community and environment, corporate governance assures that company behave in a responsible manner towards society and environment (Kolk and Pinkse, 2010). Thus, corporate governance is not only about board accountability but also include aspects of social and environment responsibility.

Earlier good governance was not a mandated legal requirement and adherence was voluntary, but owing to corporate failures on account of unethical practices at top level management, most of the countries have initiated mandatory norms and guidelines to strengthen corporate governance framework. The Cadbury Committee report in United Kingdom (UK) in 1992 and Sarbanes Oxley (SOX) Act in United States (US) in 2002 are considered a seminal development in corporate governance regulations followed by similar codes of good governance in rest of the countries. The governance codes become a source of normative institutional pressure for convergence within a country (Yoshikawa and Rasheed, 2009).

Corporate governance reforms are more significant for developing economies as they make the corporate structures more effective, help in competing with multi-national corporations and increase investors confidence (Reed, 2002). Keeping pace with the global developments, India has witnessed a series of such reforms in corporate governance. One such reform is introduction of clause 49 of listing agreement by Security Exchange Board of India (SEBI), apex regulatory authority of stock market in India. This clause outlines corporate governance structures for listed companies in India. It has led to significant implications on independent directors on board, enhanced disclosure requirements, making audit committees more powerful etc. Further, corporate governance initiatives are strengthened with the introduction of revised Company Act, 2013.

Though, corporate governance norms and other disclosure guidelines have been introduced in India but owing to weak implementation, the extent of compliance by the Indian companies is still questionable. Countries with weak legal norms have suffered 
higher depletion in exchange rates and stock market decline (Johnson, Boone, Breach and Friedman, 2000). Dharmapala and Khanna (2013) emphasize on the importance of enforcement of legal reforms in developing economies which are marred by weak systems, corruption and bureaucratic influence on policy implementation. Most of the previous studies highlight the impact of corporate governance on financial performance but surprisingly there is dearth of literature on impact of corporate governance reforms on corporate disclosures and reporting. This backdrop gives an interesting case to study the impact of reforms and amendments on improvement corporate governance disclosures in Indian companies.

Moreover, previous literature has focused on corporate governance in a particular sector like Information and Technology (IT) sector (Rajharia and Sharma, 2014a; Rajharia and Sharma, 2014b), Manufacturing sector (Saravanan, 2012), Textile sector (Ashraf, Bashir and Asghar, 2017), Banking and Financial Services (Arif and Syed, 2015) but the comparison of different sectors (Palanippan and Rao, 2015) is very limited. This study investigates the nature and type of corporate governance activities followed by top Indian companies in different sectors.

Extant research in this domain establish association between corporate governance and stock market performance (Klapper and Love, 2004; Cheung, Stouraitis and Tan, 2010; Abatecola, Caputo, Mari and Poggesi, 2012; Beiner, Drobetz, Schmid and Zimmermann, 2006; Brammer, Brooks and Pavelin, 2009; Brown and Caylor, 2006; Bauer, Guenster and Otten, 2004). However, very few studies have focused on the impact of corporate governance reforms and its linkage with financial performance. This paper investigates the plausible connection between corporate governance after reforms and firm valuations for India during two different periods of reforms on select sectors.

The paper has been organized in six sections. Background of the study is discussed in section one. Section two outlines recent developments in corporate governance norms in India. Section three reviews existing literature across economies, while section four discusses the methodology adopted. Statistical analysis of the impact of India's corporate governance reforms on firm performance is reported in section five followed by discussion, conclusion and policy implications in the last section.

\section{Recent developments in corporate governance norms in India}

Corporate governance reforms have significant importance for India which is moving towards a more transparent and accountable system of economic governance (Sanan and Yadav, 2011). The fiscal crisis in 1991 led to liberalization and privatization of Indian economy. The Indian companies required finance for growth and expansion. The need of foreign investment gave rise to the need of corporate governance reforms in India. Since then, good governance in capital market has always been on high priority for SEBI. This is evident from frequent updation of guidelines, rules and regulations by SEBI for ensuring transparency and accountability (Sehgal and Mulraj, 2008). Clause 49 was adopted by SEBI in 1999 from the code of governance developed by Confederation of Indian Industry (CII), an independent organization working with government on policy issues. It has been revised time to time to ensure better compliance.

India introduced reforms for improving corporate, social and environment disclosures. Ministry of Corporate Affairs, Government of India published 'National 
Voluntary Guidelines on Social, Environmental and Economic Responsibilities of Business' in 2011 (Ministry of Corporate Afairs, 2011). The guidelines make it mandatory for the listed companies to file Business Responsibility Report (BRR) to enhance the quality of disclosures (SEBI Circular, 2012). The enactment of the companies Act 2013 replaces the Companies Act, 1956 and aims to improve corporate governance standards to simplify regulations and enhance the interests of minority shareholders (Prasanna, 2013). India is among the first country to implement mandatory Corporate Social Responsibility (CSR) spending and this Indian model will set precedence for other countries in the world, for strategic implementation of corporate governance policies.

As per the latest revision in 2014, clause 49 includes protection of shareholders rights, proper and timely disclosures, Chief Financial Officer (CFO) certification of financial statements, equitable treatment of shareholders, enhance responsibility of board and norms for preventing insider trading. To sum up, corporate governance in India is mainly concerned with improving accountability and transparency, disciplining dominant shareholders, protecting the interest of minority shareholders. This is in contrast to US and UK which concentrates on making management more accountable to dispersed shareholders (Pande and Kaushik, 2012).

\section{Review of literature and hypothesis development} Impact of corporate governance reforms on disclosures

In general, almost all countries have issued general guidelines for governance, social and environmental reporting, but it would result only as a tick-in-the-box activity unless it is checked to what extent the corporate world is responding and reporting as per the new reforms. Many researchers have studied the impact of the recent reforms for improving governance, social and environment disclosures in different economies. In Portugal, Monteiro and Guzman (2010) explore that the extent of disclosures have improved as compared to the pre reform period but the amount of disclosures is still low even after the introduction of new reforms. Ioannou and Serafeim (2017) study the implications of disclosure reforms in China, Denmark, Malaysia and South Africa and suggest that improvement in sustainability disclosures due to introduction of reforms is associated with increase in firm value. Kolk (2008) asserts that after the reforms in disclosure regulations, many countries in Europe and in Japan have started paying attention to board supervision, ethics compliance and external verifications. Chen, Hung and Wang (2018) affirm decrease in industrial waste and Sulfur Dioxide (SO2) emissions after the declaration of disclosure mandate in China but the firms adopting CSR reporting experience decrease in profitability.

India initiated reforms concerning corporate governance, corporate social responsibility and environment to improve disclosures by Indian companies. Implementing corporate reforms, however, is significantly difficult than framing those reforms. There are many challenges in successful implementation and effective enforcement of reforms such as local inhibitions and comprehensive rules (Afsharipour, 2009), lack of availability of qualified independent directors (Malik and Nehra, 2014), underdeveloped external monitoring systems and weak and multiple regulatory norms (Rajharia and Sharma, 2014a; Rajharia and Sharma, 2014b). This gives the need to explore the actual impact of reforms on corporate governance and disclosures by Indian companies. 
There is an interesting observation about these disclosure regulations that it contains a clause of "comply or explain". It means that either the companies should comply by the norms or explain the reasons for not following the mandatory requirements. Moreover, there is no penalty for non-compliance as well. It gives an option to the companies either to follow the regulations or safely escape by giving some explanation. There may be some companies which were following the best practices in corporate governance even before these reforms were introduced. But, there may be others, which have started doing the same after these reforms. This argument justifies that there is no obvious reason to believe that reforms would result into better compliance and reporting. Therefore, it becomes important to explore the practical implications of these reforms for Indian companies and for policy makers.

Corporate governance reforms draw increased strategic attention in India. These structural changes and disclosure reforms make an interesting case to investigate their implications on Indian companies. Accordingly, this research studies the corporate governance by Indian companies after the introduction of the above stated recent reforms. No previous research has investigated the impact of these reforms considering two different periods of reforms.

Thus, the first hypothesis of the study is:

HO1: There is no significant improvement in corporate governance performance of Indian companies after the introduction of reforms.

\section{Impact of corporate governance reforms on different sectors}

Many researchers have studied the impact of corporate governance in different sectors of the economy. There is a significant impact of corporate governance on firm performance in textile sector (Ashraf et al. 2017) and in Banking and Financial services sector (Arif and Syed, 2015) in Pakistan. While comparing different sectors, Banking, Insurance and Service sector companies listed in Amman stock exchange perform better after the introduction of corporate governance reforms in Jordan (Mansur and Tangl, 2018). Jizi et al. (2014) find board independence and board size significantly related to improved CSR disclosures for banking sector in US. Okoye, Evbuomwan, Achugamonu and Araghan (2016) report a significant impact of corporate governance on banking sector in Nigeria. Palaniappan and Rao (2015) report significant impact of corporate governance disclosures on firm performance for manufacturing companies taking only one company from ten different sectors in India.

Many studies have been conducted testing the impact of corporate governance on firm performance taking a set of listed companies in varied stock exchanges across different economies. Gompers, Ishi and Metrick (2003) report better governed firms listed in New York Stock Exchange (NYSE) show higher market valuation and low expenditure. Bauer et al. (2004) reveal the same results for companies in Financial Times Stock Exchange (FTSE), Eurotop 300 index giving higher stock returns and enhanced firm valuation for the better governed companies. Studies on US listed firms also highlight positive relationship between corporate governance rankings and Tobin Q (Klapper and Love, 2004; Durnev and Kim, 2005). Similar findings are also reported in studies conducted on Italian (Abatecola et al., 2012) and Swiss (Beiner et al., 2006) firms which confirm that corporate 
governance has a significant statistical relationship with corporate performance variables like Return on Capital (ROC), Return on Assets (ROA).

An interesting observation from these studies is that most of the research has been done on a whole set of listed companies in a stock exchange or a set of listed companies in a particular sector but very few studies have done comparison of corporate governance in different sectors. Corporate governance reforms along with liberalization and privatization has led to substantial development and strategic changes in different sectors of the economy (Reed, 2002). This study investigates the nature and type of corporate governance activities, followed by top 100 listed Indian companies of different sectors, after the introduction of recent corporate governance reforms in India and tests the sector differences for two periods of reforms.

The second hypothesis of the study is:

HO2: There is no significant difference in corporate governance in different sectors in India.

\section{Corporate governance reforms and firm performance}

In general, corporate governance is considered to be a significant variable influencing growth prospects of an economy because best governance practices reduce risk for investors, improves financial performance and helps in attracting investors (Spanos, 2005). Monda and Giorgino (2013) document better corporate governance results in higher market valuation and ROA for companies listed in France, Italy, Japan, UK and US. Cheung et al. (2010) confirm that firms which have adopted corporate governance reforms appear to have better risk return trade off for investors in Hong-Kong stock market. Bae and Goyal (2010) find that good corporate governance practice adopted by Korean firms have resulted in improved equity market performance and increased foreign ownership in companies. Yang, Yan \& Yang (2012) state that improved corporate governance disclosures by US firms help in reducing cost of equity. Botosan (2006) also substantiated in an extensive literature review that proper disclosure of financial reporting and corporate governance practices help in reducing the cost of equity capital. There have been a few studies which contradict the above mentioned findings. For instance, Bhagat \& Bolton (2008) find corporate governance measures not correlated to future stock market performance for NYSE listed firms while Roodposhti and Chashmi (2010) report a negative correlation between ownership and independent board and earnings of the companies in Iran.

Similarly Indian companies are publicizing their efforts through corporate governance disclosures to attract the investors which have also led to enhancement in market valuation (Dua and Dua, 2015). Improvement in corporate governance has lead to significant increase in investment by foreign investors and profitability of Indian companies (Patibandla, 2006). Firms adopting corporate governance reforms appear to have better risk return trade off for investors (Prasanna, 2013; Mohanty, 2003). Examining the relationship between corporate governance and firm performance for firms listed in National Stock Exchange of India (Nifty 500), Shivani, Jain and Yadav (2017) find that while larger boards, committees of the board are negatively related to ROA and Return on Equity (ROE), presence of non-executive directors and whistle blower policy have positive impact. 
In contrast to the above findings, Sarpal \& Singh (2013) reports no significant relationship between board and corporate performance. Kumar (2004) specifies no significant relation between foreign shareholding and financial performance of Indian companies. Tata and Sharma (2012) find that corporate Governance practices such as board structure, ownership and other such disclosure have no significant relationship with corporate performance. Misra and Vishnani (2012) are of the view that reforms and change in corporate governance have no significant impact on the market risk of the companies listed in Group - A of Bombay Stock Exchange (BSE). The review of literature gives mixed results for Indian companies. Hence, this needs to be further scrutinized to draw any concrete conclusions.

Indian investors responded positively to clause 49 reforms initiated in 1999 and the large firms gained $4.5 \%$ on an average for three days from the date of announcement of the reforms in contract to negative reaction by investors towards SOX in developed countries (Black and Khanna, 2007). Other recent studies extend immediate positive effect into tangible long-term outcomes. Kohli and Saha (2008) report positive and significant relationship between corporate governance reforms and firms' performance. The increase in scope of clause 49 improves debt- equity structures of Indian companies (Goel and McIver, 2015). Dharmapala and Khanna (2013) put a strong case for causal effect of changes in clause 49 on firm value and underscore the significance of enforcement of regulatory norms. Clause 49 has improved stock market sentiments which result in more reliance on equity capital and less dependability on bank loans (Saher, Pal and Pinheiro, 2015).

Since a very limited literature is available to study the impact of reforms on corporate governance and firm performance, it will be interesting to evaluate the impact of changes in governance, social and environment disclosure norms on financial performance after the introduction of the recent reforms. Thus, this study explores the linkage between corporate governance and financial performance of the companies in two different periods of reforms in India.

HO3: There is no significant impact of corporate governance reforms on financial performance of Indian companies in both the periods under study.

\section{Methodology}

For this study, the researcher constructs a firm specific corporate governance performance index for Indian companies based on recent reforms introduced in the country. This paper takes into consideration two periods P1 (2012-13) and P2 (2015-16) representing two different stages of corporate governance reforms in India. The study develops an integrated empirical framework to measure the valuation effects of corporate governance mechanism.

\section{Sample and data collection}

The sample for the study is drawn from the top 100 companies ranked on the basis of revenue in the list of The Economic Times 500 (ET500), 2016. From the selected companies, 28 companies of Banking and financial services sector have been excluded from the purview of this paper as disclosure and profitability norms are different for this 
sector in India. Further, 4 companies are also excluded from the study as data for the period under study was not available. The finally selected companies have been categorized under six major sectors. Table 1 shows the sector-wise composition of the companies under study.

Published Annual Reports, Business Responsibility Reports and Sustainability Reports of the selected companies are taken as the primary source of data. These reports are collected/ downloaded from the website of the respective companies. The reports have been reviewed thoroughly to do the content analysis for the selected dimensions under study (Quick, 2008; Sandhu and Kapoor, 2010; Gautam and Singh, 2010). All the information available in the reports on a particular dimension has been collated to give the final score for each aspect. All the reports were reviewed at least twice so that no item is missed while collecting the requisite information to ensure accuracy and trustworthiness of the data. Instead of using binary score of 0 and 1 , this study gives credit to the type of reporting, the amount of information disclosed, number of good governance practices adopted by any company (Cheung et al., 2010). Scoring for different dimensions is in a range of zero to three. Financial data used in this study is mainly acquired from published data available in the Centre for Monitoring Indian Economy (CMIE) Prowess database.

\section{Measuring corporate governance}

Most of the previous studies have used only a specific aspect of corporate governance to study its implications of financial performance such as board size (Black, 2002), independent directors (Kaur and Mishra, 2010; Annalisa, P. \& Yosef, 2011), board meetings (Misra and Vishnani, 2012; Subramanian and Reddy, 2012) and code of ethics (Liao, 2010; Mittal, Sinha and Singh, 2008. This study uses a comprehensive corporate governance performance index for measuring corporate governance of Indian companies based on recent developments in corporate governance norms in India. This index is based on changes in clause 49, Company Act, 2013 and other mandatory guidelines issued by Ministry of Corporate Affairs of India. Some of the dimensions of mandatory disclosures are excluded from the study such as appointing audit committee, CFO certification of financial statements, certificate of compliance by board of directors The exclusion has been done as the pilot study done on one sector revealed that the score is same in both the periods for all the companies. Since corporate governance is based on stakeholder approach (Freeman and Evan, 1990), different stakeholders are taken as individual responsibility centers for measuring cumulative corporate governance performance to meet corporate business objectives (Barter, 2011; Clarkson, 1995). The

Table 1 Sector-wise Distribution of Selected Companies

\begin{tabular}{lll}
\hline SI.No. & Sector & No. of Companies \\
\hline 1 & Oil Power and Refinery & 14 \\
2 & Transport and Auto & 12 \\
3 & Metal, Engineering and Infrastructures & 10 \\
4 & Information Technology (IT) and Communication & 10 \\
5 & Diversified & 13 \\
6 & Pharmaceuticals and Chemicals & 9 \\
& Total & 68 \\
\hline
\end{tabular}


responsibility towards different stakeholders included in the study are shareholders (SHR), employees (EMR), suppliers and consumers (SCR), community (CMR) and environment (ENR). Table 2 elaborates the final instrument used to measure Corporate Governance Performance (CGP) index. Cronbach's alpha test of reliability of data revealed a score of 0.840 .

Using paired sample t-test corporate governance performance of each parameter in Period 1 is paired with the same in Period 2 to check the significant difference for each dimension for the two periods under study. Further, sector comparison has been done by calculating the percentage score of each sector for every stakeholder using the formula:

$$
\frac{\text { Actual Total Score of Sector for Each Stakeholder }}{\text { No.of Companies in each Sector } * \text { Total Score for Individual Stakeholder }} * 100
$$

One way Analysis of Variance (ANOVA) is applied to study the significant difference in performance of different sectors under study.

\section{Measuring financial performance}

Most of the scholars have used any one of the three approaches of measuring corporate financial performance i.e. Accounting Ratios (Griffin and Mahon, 1997; Bayoud, Kavanagh and Slaughter, 2012) or Market Valuation Ratios (Kiel and Nicholson, 2003; Arnold, Bassen and Frank, 2012) or Accounting and Market based mixed ratios (Mulyadi and Anwar, 2012). To correlate corporate governance performance with financial performance, we consider the third approach and take Tobin Q (Klapper and Love, 2004), Market Capitalization (Suttipun, 2012) and Price Earning (PE) (Siew, Balatbat and Carmichael, 2013; Tyagi, 2014) as market valuation ratios and ROS (Venanzi, 2012), ROE (Griffin and Mahon, 1997; Aggarwal, 2013) and ROA (Aupperle, Carroll and Hatfield, 1985; Tyagi, 2014) as accounting ratios.

\section{Regression model}

Regression model has been developed to examine the relationship of overall CGP score of company (independent variable - CGP taken as summation of corporate responsibility towards five different stakeholders- Shareholders, Employees, Suppliers and Customers, Community and Environment) with the financial performance of the company (dependent variables - ROS, ROA, ROE, Tobin Q, Market Cap and PE).

\section{Control variables}

Size of the company is an important control variable as Burke, Logsdon, Mitchell, Reiner and Vogel (1986) suggest that larger firms more often adopt social and governance principles and thus attract attention from stakeholders. Previous researchers have also considered risk as a factor that effects corporate social and financial performance. Thus, this relationship is studied by using size of the company as control variable calculated by natural log of total assets (Abatecola et al., 2012) and natural log of sales (Tsoutsoura, 2004) as its proxy. Additionally, beta is considered as another control variable for market risk element affecting corporate financial performance.

Six regression equations that shall be tested in this model are: 


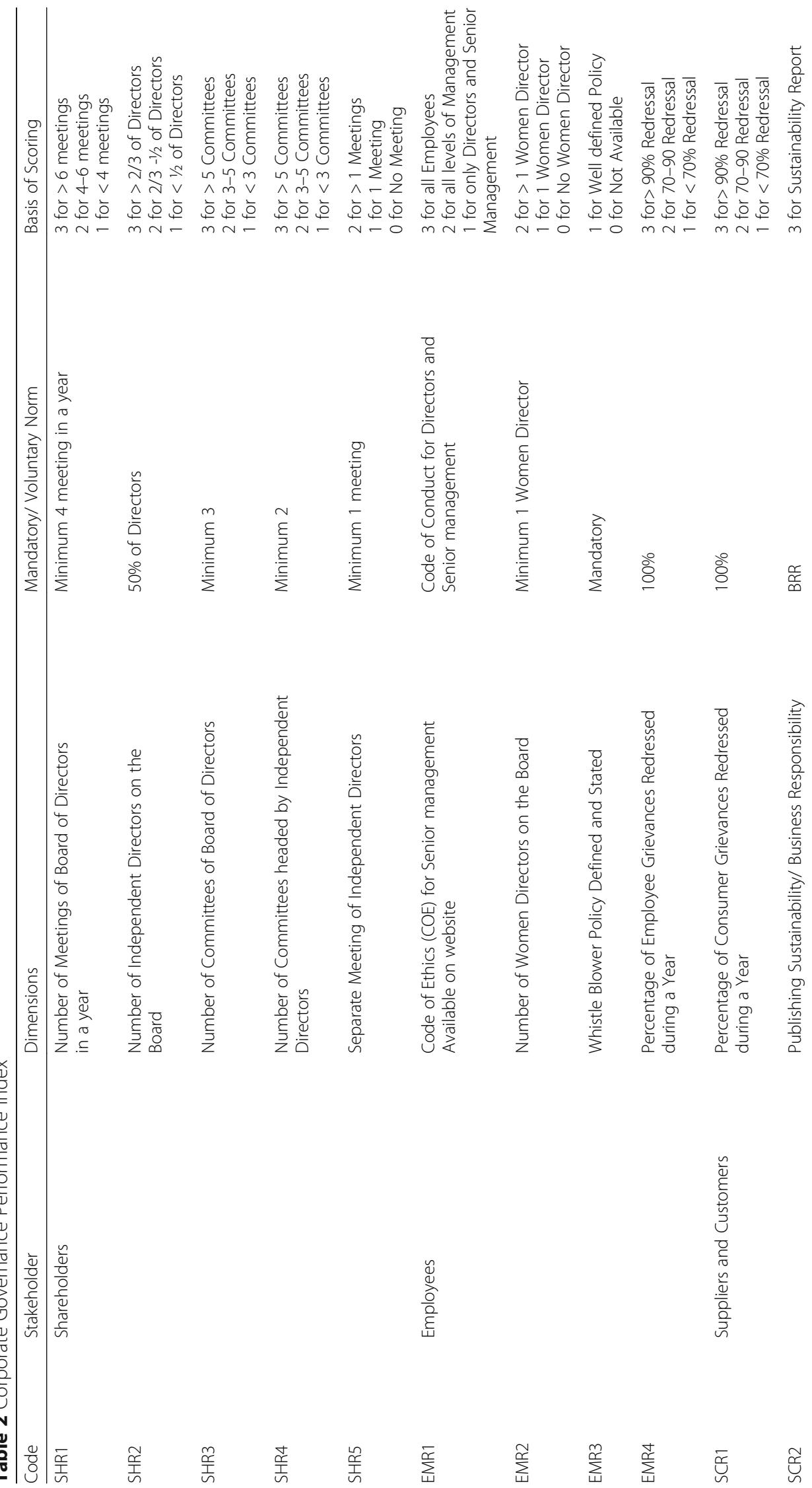




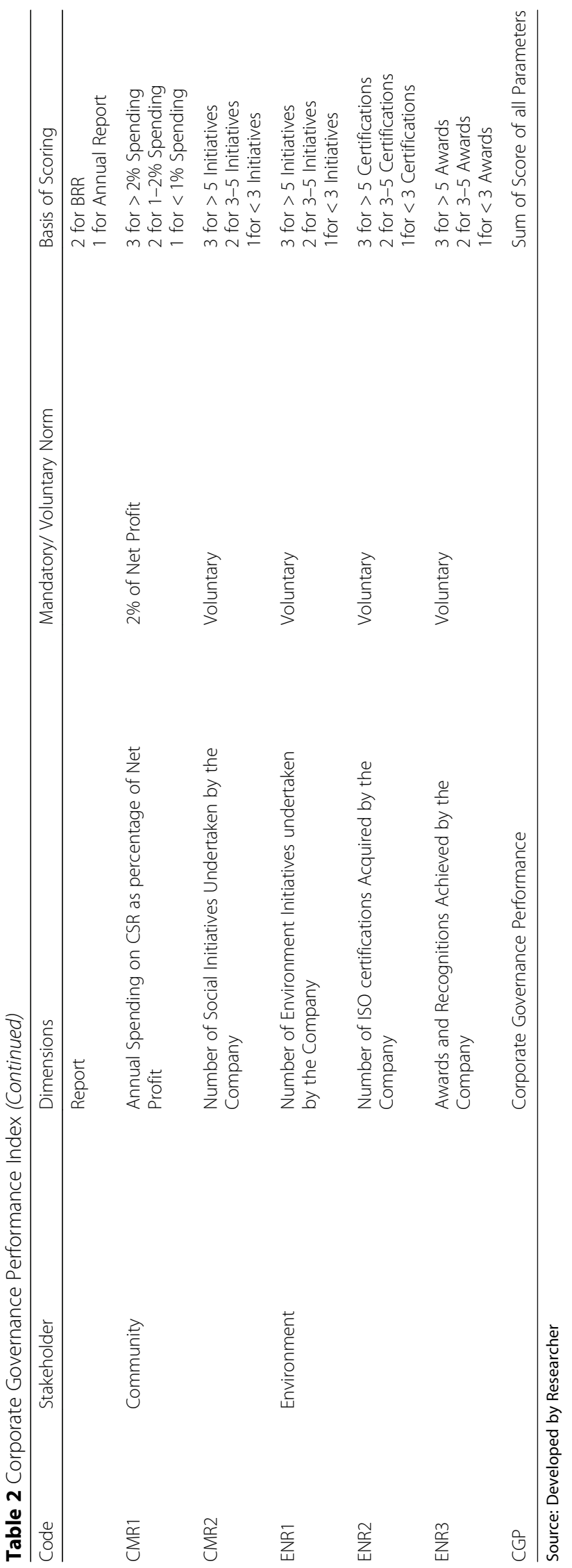


Table 3 Descriptive Statistics for CGP Towards Different Stakeholders

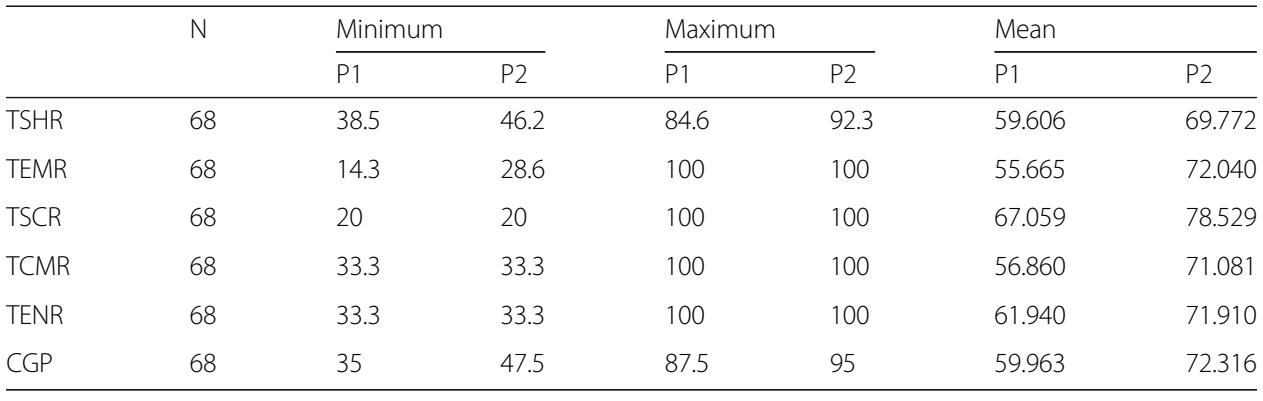

$$
\begin{aligned}
& \mathrm{ROS}=\boldsymbol{\beta}_{\boldsymbol{o}}+\sum_{k=1}^{5} \boldsymbol{\beta}_{k} \boldsymbol{C} \mathbf{G P}+\boldsymbol{\beta}_{6} \text { LnAssets }+\boldsymbol{\beta}_{7} \text { LnSales }+\boldsymbol{\beta}_{8} \text { beta }+ \\
& \mathrm{ROA}=\boldsymbol{\beta}_{\boldsymbol{0}}+\sum_{k=1}^{5} \boldsymbol{\beta}_{k} \boldsymbol{C} \text { GP }+\boldsymbol{\beta}_{6} \text { LnAssets }+\beta_{7} \text { LnSales }+\boldsymbol{\beta}_{8} \text { beta }+ \\
& \mathrm{ROE}=\boldsymbol{\beta}_{\boldsymbol{o}}+\sum_{k=1}^{5} \boldsymbol{\beta}_{k} \boldsymbol{C} \mathbf{G P}+\boldsymbol{\beta}_{6} \text { LnAssets }+\boldsymbol{\beta}_{7} \text { LnSales }+\boldsymbol{\beta}_{8} \text { beta }+ \\
& \text { Tobin } \mathrm{Q}=\boldsymbol{\beta}_{\boldsymbol{0}}+\sum_{k=1}^{5} \boldsymbol{\beta}_{k} \text { CGP }+\boldsymbol{\beta}_{6} \text { LnAssets }+\boldsymbol{\beta}_{7} \text { LnSales }+\boldsymbol{\beta}_{8} \text { beta }+ \\
& \text { Market Cap }=\boldsymbol{\beta}_{\boldsymbol{0}}+\sum_{k=1}^{5} \boldsymbol{\beta}_{k} \text { CGP }+\boldsymbol{\beta}_{6} \text { LnAssets }+\boldsymbol{\beta}_{7} \text { LnSales }+\boldsymbol{\beta}_{8} \text { beta }+ \\
& \mathrm{PE}=\boldsymbol{\beta}_{\boldsymbol{0}}+\sum_{k=1}^{5} \boldsymbol{\beta}_{k} \boldsymbol{C} \mathbf{G P}+\boldsymbol{\beta}_{6} \text { LnAssets }+\boldsymbol{\beta}_{7} \text { LnSales }+\boldsymbol{\beta}_{8} \text { beta }+
\end{aligned}
$$

\section{Data analysis}

Impact of recent reforms on corporate governance in Indian companies

Table 3 clearly depicts the improvement in mean score of each stakeholder. The introduction of governance reforms in India results in substantial increase in mean score of total corporate governance performance in P2. Further, to test the significant difference in CGP for two periods paired t-test is applied.

Table 4 depicts a significant difference in performance of each parameter in two periods as the significant $p$ value in all cases is less than 0.05 except for SHR2 i.e. having independent directors on board ( $\mathrm{p}$ value: 0.254 ) and for ENR 3 i.e. achieving awards and achievements ( $\mathrm{p}$ value: 0.321 ). Pair 17 represents cumulative CGP score and the $\mathrm{p}$ value of 0.000 shows a significant difference in overall corporate governance score of Indian companies during P1 and P2. Thus HO1 is rejected.

\section{Sector differences in corporate governance performance}

Analysis of Table 5 shows total percentage score of each sector towards each stakeholder. Over all there is improvement in CGP towards different stakeholders in each sector under study but it needs further statistical testing.

Table 6 shows the results of ANOVA to study the difference in corporate governance performance of different sectors. It gives an interesting observation that during $\mathrm{P} 1$, there is a significant difference between the sectors as the $p$ value $(0.006)$ is less than 0.05 but during $\mathrm{P} 2$, as the $\mathrm{p}$ value increases to 0.605 , there is no significant difference between different sectors for their performance towards different stakeholders. Thus, $\mathrm{HO} 2$ is accepted for post reform period. It signifies when all sectors are making efforts to contribute towards different stakeholders, the sector differences reduce in post reform period. This is a positive impact of new corporate governance reforms on Indian companies. 
Table 4 Result of Paired Samples Test for different stakeholders for Two Periods P1 and P2

\begin{tabular}{lllllllll}
\hline & & \multicolumn{2}{l}{ Paired Differences } & \\
\cline { 3 - 7 } & & & Mean & Std. Deviation & Std. Error Mean & Lower & Upper & T \\
\hline Pair 1 & SHR1 P2 - SHR1 P1 & 0.265 & 0.563 & 0.068 & 0.128 & 0.401 & $3.877^{* * *}$ \\
Pair 2 & SHR2 P2 - SHR2 P1 & -0.074 & 0.527 & 0.064 & -0.201 & 0.054 & -1.150 \\
Pair 3 & SHR3 P2 - SHR3 P1 & 0.456 & 0.679 & 0.082 & 0.292 & 0.620 & $5.539^{* * *}$ \\
Pair 4 & SHR4 P2 - SHR4 P1 & 0.221 & 0.619 & 0.075 & 0.071 & 0.370 & $2.938^{* *}$ \\
Pair 5 & SHR5 P2 - SHR5 P1 & 0.456 & 0.531 & 0.064 & 0.327 & 0.584 & $7.084^{* * *}$ \\
Pair 6 & EMR1 P2 - EMR1 P1 & 0.088 & 0.286 & 0.035 & 0.019 & 0.157 & $2.546^{*}$ \\
Pair 7 & EMR2 P2 - EMR2 P1 & 0.441 & 0.870 & 0.106 & 0.230 & 0.652 & $4.179^{* * *}$ \\
Pair 8 & EMR3 P2 - EMR3 P1 & 0.221 & 0.418 & 0.051 & 0.119 & 0.322 & $4.355^{* * *}$ \\
Pair 9 & EMR4 P2 - EMR4 P1 & 0.397 & 1.039 & 0.126 & 0.146 & 0.648 & $3.152^{* *}$ \\
Pair 10 & SCR1 P2 - SCR1 P1 & 0.250 & 0.817 & 0.099 & 0.052 & 0.448 & $2.523^{*}$ \\
Pair 11 & SCR2 P2 - SCR2 P1 & 0.324 & 0.657 & 0.080 & 0.165 & 0.482 & $4.063^{* * *}$ \\
Pair 12 & CMR1 P2 - CMR1 P1 & 0.515 & 0.837 & 0.102 & 0.312 & 0.717 & $5.068^{* * *}$ \\
Pair 13 & CMR2 P2 - CMR2 P1 & 0.338 & 0.874 & 0.106 & 0.127 & 0.550 & $3.190^{* *}$ \\
Pair 14 & ENR1 P2 - ENR1 P1 & 0.426 & 0.676 & 0.082 & 0.263 & 0.590 & $5.201^{* * *}$ \\
Pair 15 & ENR2 P2 - ENR2 P1 & 0.412 & 0.652 & 0.079 & 0.254 & 0.570 & $5.209^{* * *}$ \\
Pair 16 & ENR3 P2 - EMN3 P1 & 0.088 & 0.728 & 0.088 & -0.088 & 0.264 & 1.000 \\
Pair 17 & CGP P2 - CGP P1 & 4.794 & 4.013 & 0.487 & 3.823 & 5.766 & $9.851^{* * *}$ \\
\hline
\end{tabular}

${ }^{*} p \leq 0.05 ;{ }^{* *} p \leq 0.01 ;{ }^{* * *} p \leq 0.001$

Source: Calculated by Researcher using SPSS

Impact of corporate governance performance on financial performance

Table 7 presents the relationship between cumulative CGP score and six financial ratios using regression analysis. It is observed that CGP has positively and significantly influence on ROA, ROE and Tobin Q in P1 and only on PE in P2. Since the value of $r^{2}$ is low, only marginal variation in financial performance is explained by the model of corporate governance performance of Indian companies. The significant value of $f$ stat

Table 5 Sector Wise Average Percentage CGP Score for Different Stakeholders for 2012-13 (P1) and 2015-16(P2) \{in \%\}

\begin{tabular}{|c|c|c|c|c|c|c|c|}
\hline $\begin{array}{l}\text { Stake-holders } \\
\text { Score } \\
\downarrow\end{array}$ & $\begin{array}{l}\text { Sectors } \\
\rightarrow\end{array}$ & $\begin{array}{l}\text { Oil Power } \\
\text { Refinery }\end{array}$ & $\begin{array}{l}\text { Transport } \\
\text { and Auto }\end{array}$ & $\begin{array}{l}\text { Metal } \\
\text { Engineering } \\
\text { Infra }\end{array}$ & $\begin{array}{l}\text { IT and } \\
\text { Communi-cation }\end{array}$ & Diversified & $\begin{array}{l}\text { Pharma and } \\
\text { Chemical }\end{array}$ \\
\hline \multirow[t]{2}{*}{ Share-holders } & $\mathrm{P} 1 \%$ & 63.7 & 53.8 & 61.5 & 63.8 & 59.8 & 53.8 \\
\hline & $\mathrm{P} 2 \%$ & 67.6 & 73.1 & 65.4 & 75.4 & 68.6 & 69.2 \\
\hline \multirow[t]{2}{*}{ Employees } & $\mathrm{P} 1 \%$ & 52.0 & 44.0 & 71.4 & 55.7 & 64.8 & 46.0 \\
\hline & P2\% & 60.2 & 79.8 & 75.7 & 70.0 & 72.5 & 77.8 \\
\hline \multirow{2}{*}{$\begin{array}{l}\text { Supplier and } \\
\text { Customers }\end{array}$} & $\mathrm{P} 1 \%$ & 78.6 & 45.0 & 90.0 & 72.0 & 66.2 & 48.9 \\
\hline & $\mathrm{P} 2 \%$ & 81.4 & 63.3 & 92.0 & 76.0 & 81.5 & 77.8 \\
\hline \multirow[t]{2}{*}{ Community } & $\mathrm{P} 1 \%$ & 56.0 & 47.2 & 71.7 & 70.0 & 48.7 & 51.9 \\
\hline & $\mathrm{P} 2 \%$ & 72.6 & 63.9 & 68.3 & 78.3 & 62.8 & 85.2 \\
\hline \multirow[t]{2}{*}{ Environment } & P1\% & 66.7 & 58.3 & 54.4 & 64.4 & 61.5 & 58.2 \\
\hline & $\mathrm{P} 2 \%$ & 79.4 & 64.8 & 64.4 & 67.8 & 73.5 & 80.2 \\
\hline \multirow{2}{*}{$\begin{array}{l}\text { Corporate } \\
\text { Governance } \\
\text { Performance }\end{array}$} & $\mathrm{P} 1 \%$ & 63.0 & 51.0 & 66.8 & 64.5 & 60.2 & 54.2 \\
\hline & $\mathrm{P} 2 \%$ & 71.4 & 69.8 & 70.8 & 73.3 & 71.2 & 76.7 \\
\hline
\end{tabular}

Source: Calculated by Researcher 
Table 6 Result of ANOVA to Study Sector Differences in CGP

\begin{tabular}{lllllll}
\hline & & Sum of Squares & Df & Mean Square & F & Sig. \\
\hline Period 1 2012-13 & Between Groups & 1546 & 5 & 309 & 4.268 & 0.006 \\
& Within Groups & 1739 & 24 & 72.5 & & \\
& Total & 3285 & 29 & & & \\
Period 2 2015-16 & Between Groups & 219 & 5 & 43.9 & 0.73 & 0.605 \\
& Within Groups & 1434 & 24 & 59.7 & & \\
& Total & 1653 & 29 & & & \\
\hline
\end{tabular}

helps to conclude that there is a significant relationship between corporate governance performance and different parameters of financial performance of Indian companies in P1. There is no significant impact of corporate governance on financial performance in P2. Thus, HO3 is rejected for P1 but accepted for P2.

\section{Discussion, conclusion and policy implications}

The study attempts to answer the following questions raised in the hypothesis:

\section{Do reforms improve corporate governance in Indian companies?}

All the companies under study have implemented good governance initiatives and recognized their responsibility towards different stakeholders. The introduction of corporate governance standards through clause 49 of listing agreement has helped in improving governance standards and internal efficiency of listed companies (Sharma and Singh, 2009; Goel \& Mclver, 2015). Out of sixteen dimensions in corporate governance index, two dimensions did not show significant improvement. Indian companies need to pay attention on these dimensions namely, number of independent directors on board and achieving awards and recognitions during the year. The study finds that the number of independent directors as percentage of total directors has decreased over the period of time (Kaur and Misra, 2010). The reason may be attributed to shortage of qualified independent directors in India (Malik and Nehra, 2014; Rajharia and Sharma, 2014a, b). Further, two positive changes identified in good governance practices, which are appointing women directors on board as required by new norms and instituting diverse board committees for protecting shareholders rights. These reforms aim at making the boards more powerful and focus on monitoring the management (Dharmapala and Khanna, 2013; Dua and Dua, 2015). Accordingly, it is observed that the number of meetings of board of directors has increased. Many companies have started conducted separate meetings of independent directors. This has increased the involvement of independent directors in different committees, which have made boards more responsible and accountable to stakeholders (Shivani et al. 2017; Khan, Muttakin and Siddiqui, 2013). It is observed that most of the companies are taking care of grievances of the employees and the customers. Yet, it is quite surprising that even some of the high revenue generating companies are not reporting the grievances as per the stipulated guidelines (Chatterjee, 2011).

As per the results of the study, though the spending on CSR initiatives has increased, yet Indian Companies are still trying to match the mandatory requirement of spending $2 \%$ of their profit on CSR initiatives (Sharma, 2013). Another interesting finding is that the score for social and environment initiatives is fairly high for all the companies, 


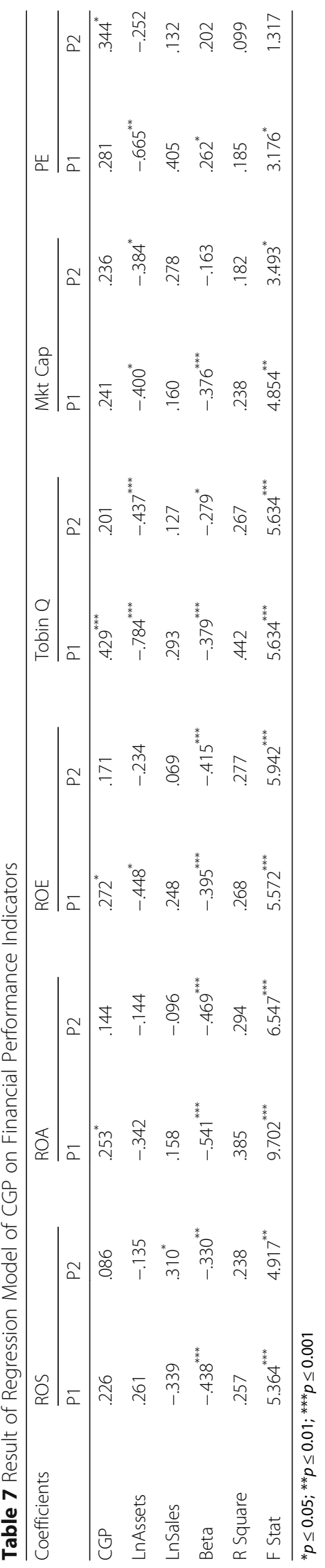


which suggests that Indian companies stress more on community welfare and environment protection in their social initiatives. This result is aligned with the previous studies done by Shanmugam \& Mohamed (2011) and Kansal and Singh (2012). Kansal, Joshi, Babu and Sharma (2018) suggest that regulators should highlight specific disclosure norms for corporate social responsibility rather than giving only general mandatory guidelines. Many companies are working under public private partnership and with Non Government Organization (NGOs) to take up social and environment issues. However, reporting on pollution and carbon emission is very low for Indian companies (Kansal et al. 2018). It has been observed that frequency of publishing sustainability reports has improved over the period (Cyriac, 2013). Further, very few Indian companies are applying for internal quality, sustainability and environment protection awards as the procedure is cumbersome.

\section{How do different sectors perform after governance reforms?}

Oil, Power and Refinery sector showed consistent responsibility towards all stakeholders during P1. This sector is dominated by public sector enterprises, which warrants them to be more adherent to the mandatory norms. IT and Communication sector, with mostly private players, also performed reasonably well in P1. Most of the Indian companies in IT sector have multinational operations with business processes outsourcing model. Hence, it becomes imperative for them to follow international norms of corporate governance, sustainability and social responsibility (Narayanaswamy, Raghunandan and Rama, 2012). Thus this comprehensive reporting helps the companies in winning the international contracts and increase revenues. However, Palaniappan and Rao (2015) suggest IT companies have a long way to go to improve their corporate governance performance.

During P2, all the sectors showed significant improvement in corporate governance score. Specifically, Pharmaceutical and Chemical sector registered a substantial increase and are at the top of the table in the cumulative score. Transport and Auto sector is at the bottom of the list in both the time periods. Though, this sector shows a significant improvement in responsibility towards shareholders and employees yet it needs to take care of environment requirements and initiate more steps for welfare of the society. Further, Metal, Engineering and Infrastructure sector has the highest score for responsibility towards suppliers and consumers in both the periods under study but they need to stress on CSR reporting (Shamim, Kumar, Soni, 2014). For diversified sector, marginal improvement in the cumulative corporate governance score is recorded.

Another significant finding of the study is that in every sector the score of top four to five companies is relatively higher than the rest of the companies. This anomaly sometimes neutralizes the high score of top companies in a particular sector. To sum up, after the introduction of mandatory and non-mandatory norms for improving corporate governance, all the sectors have initiated different programs for stakeholders. This has reduced the difference in corporate governance score between the sectors in the post reform period. Similar findings were also reported by Bhasin (2012) and Bhardwaj and Rao (2014).

\section{Do governance reforms impact financial linkage?}

Total corporate governance score is a significant predictor of company's market valuation and accounting performance. Positive direct association with Tobin q, ROA and 
ROE is captured in the period P1. Hence, the study concludes that better corporate governance performance leads to better financial performance in term of revenue and growth. Similar findings have been reported by earlier studies (Cortez and Cudia, 2011; Love and Klapper, 2002). In Japan, Bauer, Frijns, Otten, Rad (2008) find disclosures related to shareholders rights, remuneration and internal control, impact firm performance but disclosures related to board accountability do not affect stock prices. Studies conducted in Indian context also find a positive impact of corporate governance reforms on firm performance (Mohanty, 2003; Rajput et al., 2012, Arora and Bodhanwala, 2018). Even in other developing economies like Pakistan, Ashraf et al. (2017); Arif and Syed (2015) find significant relationship between corporate governance and financial performance. However in Nigeria after the introduction or corporate governance norms, Sanda, Mikailu and Garba, (2005) report that presence of outside directors does not influence firm performance but the existence of expatriate Chief executive officers does. The regulatory authorities in Nigeria need to ensure strict compliance to improve the impact of reforms (Okoye et al., 2016). Mansur and Tangl (2018) find that after the introduction of governance code in Jordan, the presence of institutional investors in ownership structures help in improving firm performance in stock market.

However, an interesting finding for Indian companies is that after the introduction of the new governance reforms, the corporate governance performance improves but its impact on financial performance decreases. The study did not find any significant impact on market valuation ratios and accounting ratios in post reform period (Tripathi \& Seth, 2014; Aggarwal, 2013). Hence, governance reforms actually do not impact financial linkages in Indian market during post reform period.

\section{Conclusion and policy implications}

This research concludes that Indian companies have made significant development in corporate governance after the introduction of recent reforms. Over all, it is observed that the main objective of the reforms has been achieved by making the board more responsible towards all stakeholders. The introduction of having at least one women director on board is a significant development for Indian companies. Regulators may further enhance women representation on board to improve gender parity at top management. Indian companies should appoint more number of independent directors as the role of independent directors becomes very significant for the successful implementation of these reforms. The target set for mandatory $2 \%$ spending of net profits on CSR is still not achieved to full extent. Hopefully, in near future when the companies are able to identify the core areas of social responsibility, this Indian model can bring miracles for the development of the society. As a result, these philanthropic initiatives may yield better return on social investment. The mandatory publishing of business responsibility reports has improved disclosures for economic and social responsibility. Regulators should make disclosure of carbon foot prints mandatory to bring more awareness and responsibility towards environment. Initiating appropriate corporate governance rewards in different sectors would also encourage companies to follow the regulations and showcase their contribution towards society and environment.

All the sectors have endeavored to improve corporate governance performance as the investors have started recognizing good governance companies and this can also be 
used as a tool for attracting foreign investors. Government should try to address sector specific issues to raise the standards of performance. Although in light of these reforms, corporate governance has gained substantial ground in India, but this study does not find any significant impact of reforms on financial performance of the companies. As and when the corporate governance reforms are implemented in true spirit, the market sentiments would change and improve the relationship between corporate governance and firm performance in India similar to developed economies.

To cater to the problem of compliance and implementation of governance reforms in view of strong interference of bureaucracy and corruption in India, market regulators should be made more powerful and given a free hand to prosecute the companies involved in frauds. Also, high penalties should be imposed for non-adherence of mandatory requirements. Thus, the full implementation of governance reforms in India requires reforms to take place in larger context including political and legal systems. Moreover, the Indian companies need to understand the benefits of implementing good governance strategies and corresponding initiatives that help in improving financial performance as well.

This study has certain limitations. The annual reports have been reviewed multiple times to validate the reported aspects and achieve higher consistency while giving the rating score, still the subjectivity inherent in the rating scale remains a limitation. Additionally, financial data and corporate governance performance has been considered for two years and for top hundred companies only. Future study can extend this data for multiple years and investigate the relationship as a trend analysis for all ET500 companies. As the global investors are ready to pay premium to the companies who are investing in sustainable practices for stakeholders, even the domestic investors may also follow the same trend and attach more value to the well governed companies embracing corporate responsibility.

Acknowledgements

Not Applicable.

Funding

No Funding has been received from any agency for this research paper.

Availability of data and materials

1. The datasets related to financial performance generated during and/or analysed during the current study are available in the CMIE Prowess database, https://prowessiq.cmie.com/

2. The datasets related to corporate social performance index generated during and/or analyzed during the current study are available from the corresponding author on reasonable request.

Authors' contributions

This is a single author paper. All data has been generated and analyzed by the corresponding author only, which has been presented in the final manuscript.

Competing interests

The authors declare that they have no competing interests.

\section{Publisher's Note}

Springer Nature remains neutral with regard to jurisdictional claims in published maps and institutional affiliations.

Received: 17 May 2018 Accepted: 23 October 2018

Published online: 06 November 2018

References

Abatecola G, Caputo A, Mari M, Poggesi S (2012) Relations among corporate governance, codes of conduct, and the profitability of public utilities: an empirical study of companies on the Italian stock exchange. Int J Manag 29(2):611-626 
Afsharipour A (2009) Corporate governance convergence: lessons from the Indian experience. Nw J Int'l L \& Bus 29:335 Aggarwal P (2013) Impact of sustainability performance of company on its financial performance: a study of listed Indian companies

Annalisa P, Yosef S (2011) Corporate governance and earnings Management in Family-Controlled Companies. J Acc Audit Financ 26:199-227. https://doi.org/10.1177/0148558X11401212

Arif K, Syed N (2015) Impact of corporate governance on performance of a firm: a comparison between commercial banks and financial services companies of Pakistan. European Journal of Business and Management 7(10):54-60

Arnold MC, Bassen A, Frank R (2012) Integrating sustainability reports into financial statements: an experimental study

Arora A, Bodhanwala S (2018) Relationship between corporate governance index and firm performance: Indian evidence. Glob Bus Rev 19(3):675-689

Ashraf M, Bashir A, Asghar N (2017) Impact of corporate governance on firms' financial performance: textile sector of Pakistan. International Journal of Business and Management Invention 6(5):13-19

Aupperle KE, Carroll AB, Hatfield JD (1985) An empirical examination of the relationship between corporate social responsibility and profitability. Acad Manag J 28(2):446-463

Bae KH, Goyal VK (2010) Equity market liberalization and corporate governance. J Corp Finan 16(5):609-621

Barter, N. (2011). Stakeholder theory: pictures, the environment and sustainable development $\{$ u2013\} do we have a good enough picture in our heads or do we need something different? Asia Pacific Centre for Sustainable Enterprise

Bauer R, Frijns B, Otten R, Tourani-Rad A (2008) The impact of corporate governance on corporate performance: evidence from Japan. Pac Basin Financ J 16(3):236-251

Bauer R, Guenster N, Otten R (2004) Governance in Europe: the effecton stock returns, firm valueand performance. J Asset Manag 5(2):91-104

Bayoud NS, Kavanagh M, Slaughter G (2012) Corporate social responsibility disclosure and corporate reputation in developing countries: the case of Libya. Journal of Business and Policy Research 7(1):131-160 ISSN 1838-3742

Beiner S, Drobetz W, Schmid MM, Zimmermann H (2006) An integrated framework of corporate governance and firm valuation. Eur Financ Manag 12(2):249-283

Bhagat S, Bolton B (2008) Corporate governance and firm performance. J Corp Finan 14(3):257-273

Bhardwaj MN, Rao CDBR (2014) Corporate governance practices in India - a case study. Asia Pacific Journal of Research, I (12), 43-54.

Bhasin M (2012) Voluntary'Corporate governance disclosures made in the annual reports: an empirical study. International Journal of Management \& Innovation 4(1)

Black BS (2002) The non-correlation between board Independence and long-term firm performance. Journal of Corporation Law 27:231-274

Black BS, Khanna VS (2007) Can corporate governance reforms increase firm market values? Event study evidence from India. J Empir Leg Stud 4(4):749-796

Botosan CA (2006) Disclosure and the cost of capital: what do we know? Account Bus Res 36(sup1):31-40

Brammer S, Brooks C, Pavelin S (2009) The stock performance of America's 100 best corporate citizens. Q Rev Econ Finance 49(3):1065-1080

Brown LD, Caylor ML (2006) Corporate governance and firm valuation. J Account Public Policy 25(4):409-434

Burke L, Logsdon JM, Mitchell W, Reiner M, Vogel D (1986) Corporate community involvement in the San Francisco Bay Area. Calif Manag Rev XXVIII(3):122-141

Chatterjee D (2011) A content analysis study on corporate governance reporting by Indian companies. Corp Reput Rev 14(3): 234-246

Chen YC, Hung M, Wang Y (2018) The effect of mandatory CSR disclosure on firm profitability and social externalities: evidence from China. J Account Econ 65(1):169-190

Cheung Y-L, Stouraitis A, Tan W (2010) Does the quality of corporate governance affect firm valuation and risk? Evidence from a corporate governance scorecard in Hong Kong. International Review of Finance 10:403-432. https://doi.org/10. 1111/j.1468-2443.2010.01106.x

Clarkson MBA (1995) A stakeholder framework for analyzing and evaluating corporate social performance. Acad Manag Rev 20(1):92-117

CORTEZ MAA, CUDIA CP (2011) Sustainability and firm performance: a case study of Japanese electronics companies. Ritsumeikan international affairs 10:321-339

Cyriac S (2013) Corporate sustainability reporting practices: a comparative study of practices by Indian and European companies. The Macrotheme Review 2(6):38-46

Dharmapala D, Khanna V (2013) Corporate governance, enforcement, and firm value: evidence from India. J Law Econ Org 29(5):1056-1084

Dua P, Dua S (2015) A review article on corporate governance reforms in India. International Journal of Research 2(2):806-835

Durnev A, Kim EH (2005) To steal or not to steal: firm attributes, legal environment, and valuation. J Financ 60:1461-1493

Ehikioya Bl (2009) Corporate governance structure and firm performance in developing economies: evidence from Nigeria. Corporate Governance: The international journal of business in society 9(3):231-243

Freeman RE, Evan WM (1990) Corporate governance: a stakeholder interpretation. J Behav Econ 19(4):337-359

Gautam R, Singh A (2010) Critical environmental indicators used to assess environmental performance of business. Glob Bus Manag Res 2(2):224-236

Goel K, Mclver R (2015) INDIA'S corporate governance reforms and listed CORPORATIONS'CAPITAL structures. Delhi Business Review 16(2)

Gompers P, Ishi JL, Metrick A (2003) Corporate governance and equity prices. Q J Econ 118(1):107-155

Griffin, J.J. \& Mahon, J,F. (1997). The corporate social performance and corporate financial performance debate: Twenty five years of incomparable research. Business and Society. 36(1). 5-31

loannou I, Serafeim G (2017) The consequences of mandatory corporate sustainability reporting

Jizi MI, Salama A, Dixon R, Stratling R (2014) Corporate governance and corporate social responsibility disclosure: evidence from the US banking sector. J Bus Ethics 125(4):601-615 
Johnson S, Boone P, Breach A, Friedman E (2000) Corporate governance in the Asian financial crisis. J Financ Econ 58(1-2): 141-186

Kansal M, Joshi M, Babu S, Sharma S (2018) Reporting of corporate social responsibility in central public sector enterprises: a study of post mandatory regime in India. J Bus Ethics 151(3):813-831

Kansal M, Singh S (2012) Measurement of corporate social performance: an Indian perspective. Social responsibility journal 8(4):527-546

Kaur G, Mishra R (2010) Corporate Governance Failure in India: A Study of Academicians Perception. IUP Journal of Corporate Governance, IX: (1): 99-112

Khan A, Muttakin MB, Siddiqui J (2013) Corporate governance and corporate social responsibility disclosures: evidence from an emerging economy. J Bus Ethics 114(2):207-223

Kiel GC, Nicholson GJ (2003) Board composition and corporate performance: how the Australian experience informs contrasting theories of corporate governance. Corp Gov 11(3):189-205

Klapper LF, Love I (2004) Corporate governance, investor protection, and performance in emerging markets. J Corp Finan 10(5):703-728

Kohli N, Saha GC (2008) Corporate governance and valuations: evidence from selected indian companies. Int J Discl Gov 5(3): 236-251. https://doi.org/10.1057/jdg.2008.10

Kolk A (2008) Sustainability, accountability and corporate governance: exploring multinationals' reporting practices. Bus Strateg Environ 17(1):1-15

Kolk A, Pinkse J (2010) The integration of corporate governance in corporate social responsibility disclosures. Corp Soc Responsib Environ Manag 17(1):15-26

Kumar J (2004) Does corporate governance influence firm value? Evidence from Indian firms. The Journal of Entrepreneurial Finance \& Business Ventures 9(2):61-91

Liao WC (2010) The relationship between ethics training and employee satisfaction: a mediator of corporate responsibility practices. The Journal of Human Resource and Adult Learning 6(1):9

Love I, Klapper LF (2002) Corporate governance, investor protection, and performance in emerging markets. Journal of Corporate Finance 10(5):703-728

Maier S (2005) How global is good governance? Ethical Investment Research Services, London

Malik S, Nehra VS (2014) Corporate governance and firms performance: review of research in the light of recent reforms in India. Pacific Business review International 6(7):77-84

Mansur H, Tangl A (2018) The Effect of Corporate Governance on the Financial Performance of Listed Companies in Amman Stock Exchange (Jordan). Journal of Advanced Management Science Vol, 6(2), 97-102.

Ministry of corporate affairs (MCA), India (2011). http://www.mca.gov.in/Ministry/latestnews/National_Voluntary_Guidelines_ 2011_12jul2011.pdf

Misra D, Vishnani S (2012) Impact of corporate governance regulation on market risk. Vikalpa 37(2):19-32

Mittal RK, Sinha N, Singh A (2008) An analysis of linkage between economic value added and corporate social responsibility Manag Decis 46(9):1437-1443. https://doi.org/10.1108/00251740810912037

Mohanty P (2003) Institutional investors and corporate governance in India

Monda B, Giorgino M (2013) Corporate governance and shareholder value in listed firms: an empirical analysis in five countries (France, Japan, Italy, UK, USA). Corporate Ownership \& Control 10(3):36-50

Monteiro DS, Guzmán SMAB (2010) Determinants of environmental disclosure in the annual reports of large companies operating in Portugal. Corporate Social Responsibility and Environmental Journal 17(4):185-204

Mulyadi MS, Anwar Y (2012) Impact of corporate social responsibility toward firm value and profitability. The Business Review, Cambridge 19(2):316-322

Narayanaswamy R, Raghunandan K, Rama DV (2012) Corporate governance in the Indian context. Account Horiz 26(3):583-599

Okoye LU, Evbuomwan GO, Achugamonu BU, Araghan I (2016) Impact of corporate governance on the profitability of the Nigerian banking sector. ESUT Journal of Accountancy 7(1):281-292

Palaniappan G, Rao S (2015) Relationship between corporate governance practices and firms performance of Indian context. International Research Journal of Engineering and Technology 3(3):1-5

Pande, S., \& Kaushik, K. V. (2012). Study on the state of corporate governance in India-evolution, issues and challenges for the future. Indian Institute of Corporate Affairs

Patibandla M (2006) Equity pattern, corporate governance and performance: a study of India's corporate sector. J Econ Behav Organ 59(1):29-44

Prasanna PK (2013) Impact of corporate governance regulations on Indian stock market volatility and efficiency. Int J Discl Gov 10(1):1-12

Quick R (2008) Voluntary sustainability reporting practices in Germany: a study on reporting quality. Portuguese Journal of Accounting and Management 5(1):7-35

Rajharia P, Sharma B (2014a) Corporate Governance In India Evolution, Issues And Challenges For The Future. International Journal of Scientific Research and Management 2

Rajharia, P., \& Sharma, B. (2014b). Legal Aspects of Corporate Governance for IT Companies in India, 2(11), 35-42

Rajput N, Batra G, Pathak R (2012) Linking CSR and financial performance: an empirical validation. Probl Perspect Manag 10(2):42-49

Reed D (2002) Corporate governance reforms in developing countries. J Bus Ethics 37(3):223-247

Roodposhti FR, Chashmi SN (2010) The effect of board composition and ownership concentration on earnings management: evidence from Iran. World Academy of Science. Eng Technol 66:165-171

Saher, Z., Pal, S., \& Pinheiro, T. (2015). Regulations and firm Financing : impact of clause 49 in India * regulations and firm Financing : impact of clause 49 in India, (October).

Sanan N, Yadav S (2011) Corporate governance reforms and financial disclosures: a case of Indian companies. IUP Journal of Corporate Governance 10(2)

Sanda AU, Mikailu AS, Garba T (2005) Corporate governance mechanisms and firm financial performance in Nigeria

Sandhu HS, Kapoor S (2010) Corporate social responsibility initiatives: an analysis of voluntary corporate disclosure. South Asian J Manag 17(2):47 
Saravanan P (2012) In: Under Ministry of Corporate Affairs (ed) Corporate governance and company performance- a study with reference to manufacturing firms in India

Sarpal S, Singh F (2013) Board size and corporate performance: an empirical investigation. International Journal of Business Ethics in developing economies 2(1):1

Securities Exchange Board of India (SEBI), Circular. (2012). Business Responsibility Reports. Retrieved 19 June 2015, From http://www.sebi.gov.in/cms/sebi_data/attachdocs/1344915990072.pdf

Sehgal A, Mulraj J (2008) Corporate governance in India: moving gradually from a regulatory model to a market-driven model_a survey. Int J Discl Gov 5(3):205-235

Shamim A, Kumar M, Soni P (2014) Corporate governance: an analysis of impact of corporate governance on profit of companies. International Research Journal of Commerce, Arts. Science 5(12):19-31

Shanmugam K, Mohamed SN (2011) A study on CSR initiatives in Indian automobile industry. Interdisciplinary Journal of Contemporary Research in Business 3(6):85-100

Sharma B (2013) India Inc's evolving corporate social responsibility landscape- from voluntary to mandatory. The Chartered Accountant, May, pp 73-76

Sharma R, Singh F (2009) Voluntary corporate governance disclosure: a study of selected companies in India. IUP Journal of Corporate Governance 8(3/4):91

Shivani, M. V., Jain, P. K., \& Yadav, S. S.(2017) GOVERNANCE STRUCTURE AND ACCOUNTING RETURNS: STUDY OF NIFTY500 CORPORATES

Siew RYJ, Balatbat MCA, Carmichael DG (2013) The relationship between sustainability practices and financial performance of construction companies. Smart and Sustainable Built Environment 2(1):6-27

Spanos $\sqcup$ (2005) Corporate governance in Greece: developments and policy implications. Corp Gov 5(1):15-30

Subramanian S, Reddy VN (2012) Corporate governance disclosures and international competitiveness: a study of Indian firms. Asian Business \& Management 11(2):195-218

Suttipun M (2012) Triple bottom line reporting in annual reports: a case study of companies listed on the Stock Exchange of Thailand (SET). Asian Journal of Finance \& Accounting 4(1):69-92

Tadesse S (2004) The allocation and monitoring role of capital markets: theory and international evidence. J Financ Quant Anal 39(4):701-730

Tata SV, Sharma M (2012) Corporate governance mechanisms and firm performance: a study of Indian firms. Journal of Commerce and Accounting Research 1(1):11-17

Tripathi V, Seth S (2014) The Link Between Corporate Social And Financialperformance Of Nifty 50 Companies In India. Aspirare. 1, 48-70.

Tsoutsoura M (2004) Corporate social responsibility and financial performance

Tyagi R (2014) CSR bequeath competitive advantage: a relative study of indian firms. International Journal of Management Research and Business. Strategy 3(3):49-69

Venanzi, D. (2012). Social ratings and financial performance: An instrumental approach. Available at SSRN

Yang IH, Yan LI, Li Y, Yang H (2012) Disclosure and the cost of equity capital: an analysis at the market level

Yoshikawa T, Rasheed AA (2009) Convergence of corporate governance: critical review and future directions. Corporate Governance: An International Review 17(3):388-404

\section{Submit your manuscript to a SpringerOpen ${ }^{\circ}$ journal and benefit from:}

- Convenient online submission

- Rigorous peer review

- Open access: articles freely available online

- High visibility within the field

- Retaining the copyright to your article

Submit your next manuscript at $\mathbf{s p r i n g e r o p e n . c o m ~}$ 